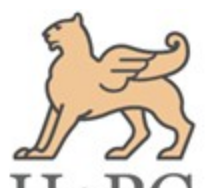

\title{
Genus Notoscyphus Mitt. - New to the liverwort flora of the Eastern Ghats
}

\author{
A.E.D. Daniels, M.M. Preetha, V. Asha, P. Monisha and P.M. Biju \\ Bryology Laboratory, Department of Botany \& Research Centre, Scott Christian College (Autonomous), Nagercoil 629003, India
}

Article history

Received: 03 February 2018

Accepted: 10 April 2018

Published: 25 April 2018

(C) Daniels et al (2018)

\section{Editor}

K K Sabu

\section{Publisher}

Horizon e-Publishing Group

Correspondence

Albert Ebenezer Dulip Daniels

$\bigotimes$ dulipdaniels@yahoo.co.uk

\begin{abstract}
Notoscyphus paroicus Schiffn. has been discovered in the Kolli Hills of Eastern Ghats. The genus is new to the liverwort flora of this region. A brief description with figures and photo plate is provided.
\end{abstract}

\section{Keywords}

Marchantiophyta; Notoscyphus paroicus; Eastern Ghats

\section{Citation}

Daniels AED, Preetha MM, Asha V, Monisha P, Biju PM. Genus Notoscyphus Mitt. - New to the liverwort flora of the Eastern Ghats. Plant Science Today 2018;5(2):81-83. https://dx.doi.org/10.14719/pst.2018.5.2.377

\section{Introduction}

In India Notoscyphus Mitt. is represented by four species namely $N$. darjeelingensis Udar \& Ad. Kumar var. darjeelingensis, N. lutescens (Lehm. \& Lindenb.) Mitt., N. pandei Udar \& Ad. Kumar and N. paroicus Schiffn., and one variety $N$. darjeelingensis var. sikkimensis D. Singh \& al. [1]. All the four species occur in the Western Ghats barring the lone variety $[1,2]$. However, none of these species has been reported from the Eastern Ghats so far [3, 4]. The present discovery of $N$. paroicus in Kolli Hills fills this lacuna thereby adding one more genus to the liverwort flora of the Eastern Ghats. The same has been described and illustrated.

Notoscyphus paroicus Schiffn., Denkschr. Kaiserl. Akad. Wiss., Wien Math.-Naturwiss. Kl. 67: 192. 1898; Udar \& Ad. Kumar, J. Hattori Bot. Lab. 49: 258. 1981. - Type: Java (Indonesia), Batavia Province, in the field of Buitenzorgensi,
Kampong Baru, alt. ca 230 m.s.m, 11.03.1894, 486 (G). (Figs. 1 \& 2)

Plants prostrate to suberect, $7-10 \mathrm{~mm}$ long, $1.2-3.8 \mathrm{~mm}$ wide including leaves, yellowish-green to pale green; branching ventral intercalary. Stems $0.22-0.4 \mathrm{~mm} \times 0.2-0.3 \mathrm{~mm}$; cells thin-walled, 4-16 $\times 4-8 \mu \mathrm{m}$, irregularly quadrate-hexagonal, homogenous. Leaves imbricate, obliquely spreading, $0.5-1.75 \times 0.4-$ $0.9 \mathrm{~mm}$, quadrate-oblong to oblong-ovate, entire, more or less rounded at apex; cells thin-walled, with distinct bulging trigones; apical leaf cells $12-20 \times 12-16 \mu \mathrm{m}$; median leaf cells $8-20 \times 8-12$ $\mu \mathrm{m}$; basal leaf cells $12-24 \times 8-16 \mu \mathrm{m}$; oil bodies seen disintegrated; cuticle faintly granulose. Underleaves distant, bilobed to more than half its length, $0.55-0.68 \times 0.4-0.45 \mathrm{~mm}$, with a slime papilla at apex, entire, sometimes with an accessory tooth at lateral margin. Rhizoids clustered at underleaf base. Pseudoperianth or sporogonium not seen. 


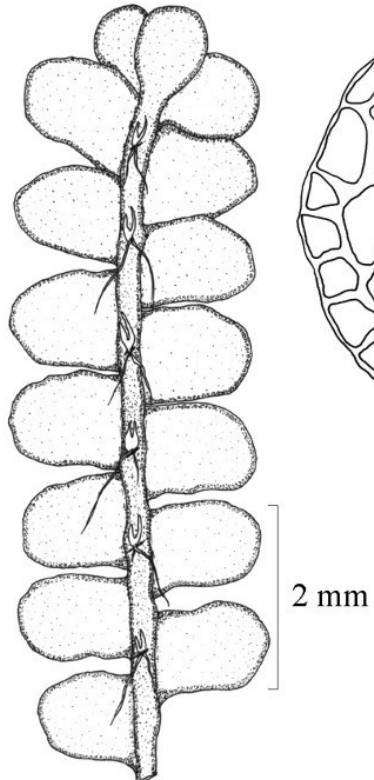

A

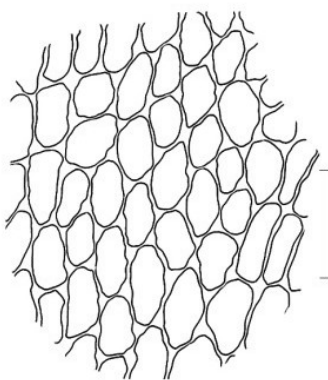

E
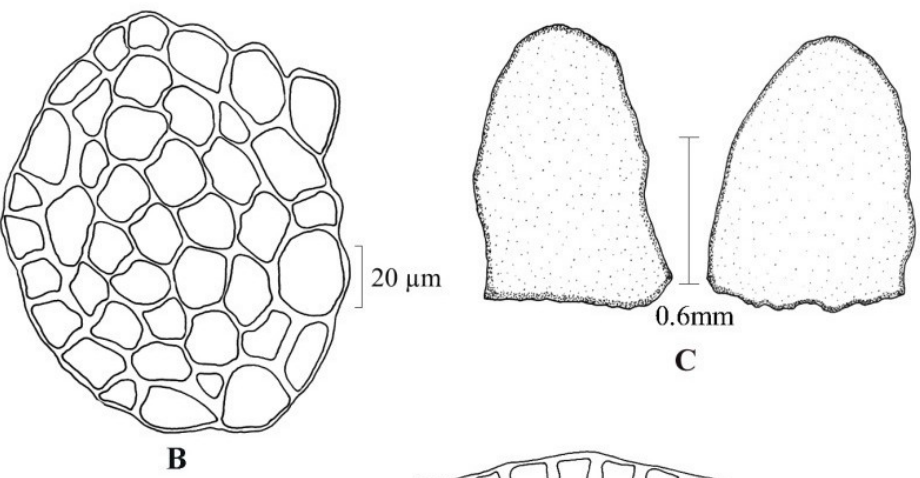

C

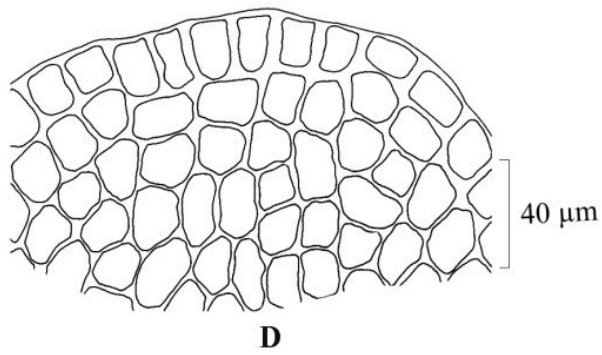

D

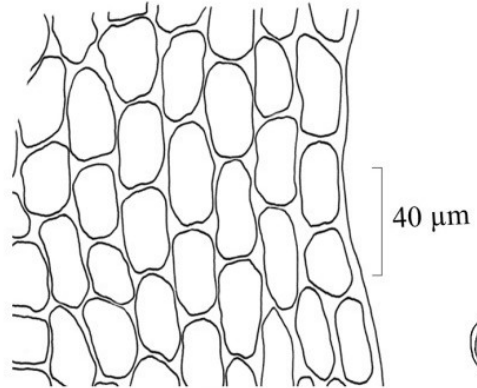

F

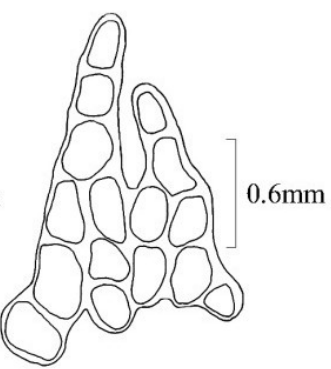

G

Fig. 1 (A-G). Notoscyphus paroicus Schiffn.

A. Portion of plant B. Cross section of stem C. Leaves D. Leaf apical cells

E. Leaf median cells F. Leaf basal cells G. Under leaf (P.M. Biju 1498)

Habitat: Terricolous, growing in degraded evergreen forests, at an altitude of ca $1240 \mathrm{~m}$.

Distribution: India: Northeast India (Meghalaya), W. Ghats of Karnataka, Kerala and Tamil Nadu (Madurai and Nilgiri) and Eastern Ghats of Tamil Nadu (Namakkal District); Indonesia, Japan, Malaysia, the Philippines, Sri Lanka and Vietnam.

Specimens examined: Eastern Ghats: Tamil Nadu, Namakkal District, Kolli Hills, Perumakka Shola, ca 1240 m, 21.1.2016, P.M. Biju 1498 (SCCN).

\section{Discussion}

According to Vàňa and Piippo [5], Notoscyphus paroicus and $N$. lutescens are hardly separable owing to the highly variable vegetative and sporophytic characters of both species and opined to treat them as a complex. Vàña and Long [6] state that they prefer to follow Vàña \& Piippo [5] against a pending detailed revision and molecular study. Long and Rubasinghe [7] have followed Vàna and Long [6]. Since the circumscription of the species still remains unresolved, we treat $N$. paroicus as a distinct entity following Singh et al. [1].

Northeast India is a separate geographical unit and not a part of Eastern Himalaya as visualized by Singh and Nath [8]. Hence, in the distribution, Meghalaya is given under Northeast India and not under Eastern Himalaya.

\section{Authors' contribution}

AEDD - Collection, determination and preparation of the MS; MMP - Dissection and preparation of colour plate; VA - Dissection and preparation of figures; PM - Dissection and help in determination; PMB - Collection.

\section{Acknowledgements}

The authors thank the Tamil Nadu State Forest Department for permission to explore the study area and help in the field, the Ministry of Environment, Forests \& Climate Change, Govt. of 


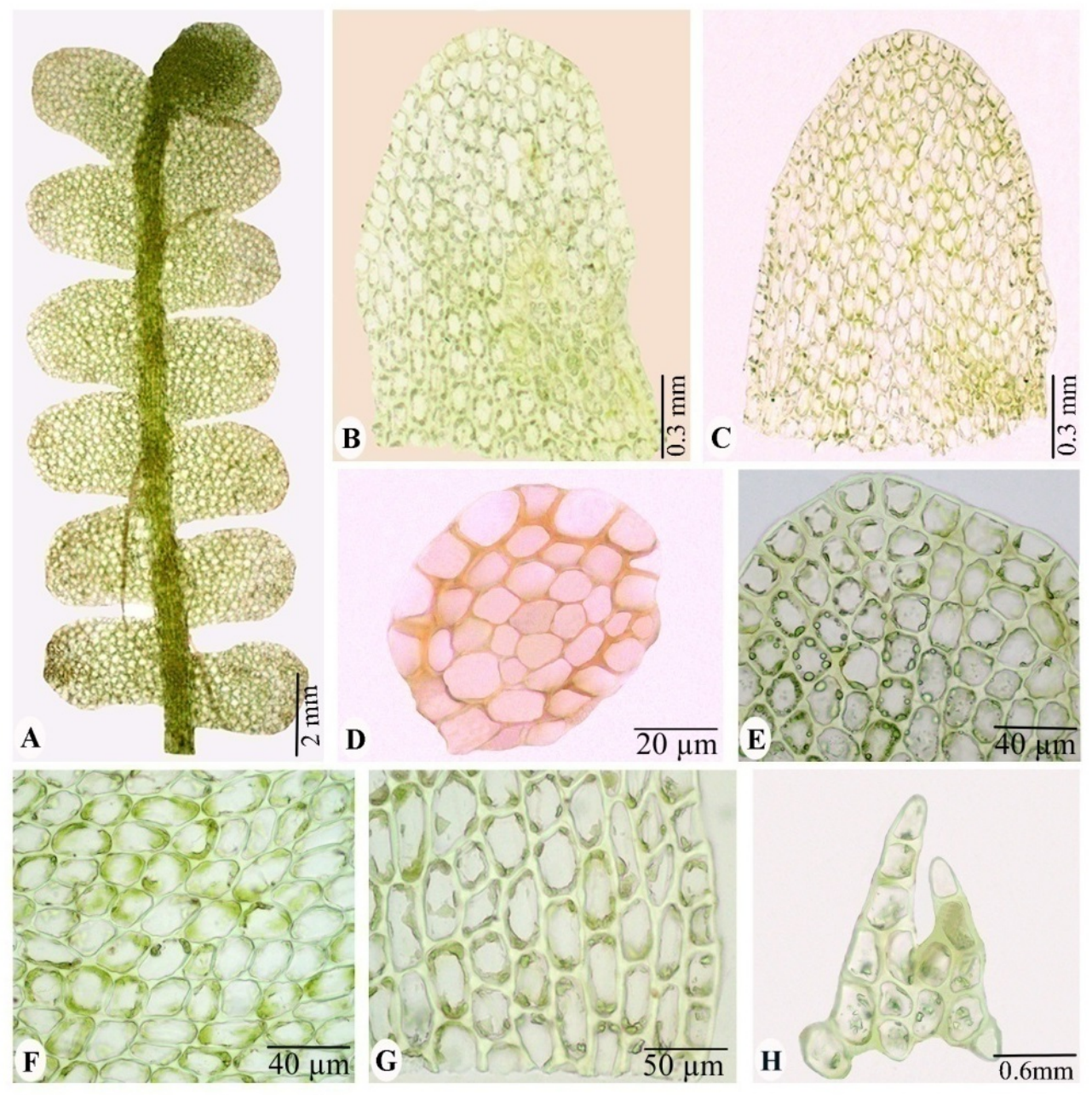

Fig. 2 (A-H). Notoscyphus paroicus Schiffn.

A. Portion of plant B\&C. Leaves D. Cross section of stem E. Leaf apical cells F. Leaf median cells G. Leaf basal cells H. Underleaf (P.M. Biju 1498)

India, New Delhi, for financial assistance, and the Principal, Scott Christian College, for facilities.

\section{Conflict of interest}

The authors declare that they have no competing interests.

\section{References}

1. Singh DK, Singh SK, Singh D. Liverworts and Hornworts of India, an annotated checklist. Kolkata: Botanical Survey of India; 2016. P. 1-439.

2. Udar R, Kumar A. Genus Notoscyphus Mitt. in India. J Hattori Bot Lab. 1981; 49: 247-260.

3. Daniels AED. Checklist of the bryophytes of Tamil Nadu. Arch Bryol. 2010; 65: 1-118.
4. Dandotiya D, Govindapyari H, Suman S, Uniyal PL. Checklist of the bryophytes of India. Arch Bryol. 2011; 88: 1-126.

5. Vàn̆a J, Piippo S. Bryophyte flora of the Huon Peninsula, Papua New Guinea. XXIX. Jungermanniaceae and Gymnomitriaceae (Hepaticae). Ann Bot Fenn. 1989; 26: 107-125.

6. Vàňa J, Long DG. Jungermanniaceae of the SinoHimalayan region. Nova Hedwigia 2009; 89: 485517. https://doi.org/10.1127/0029-5035/2009/00890485

7. Long DG, Rubasinghe SCK. Liverworts and hornworts of Sri Lanka: a revised checklist. Ceylon J Sci (Bio Sci.) 2014; 43: 1-36.

8. Singh AP, Nath V. Hepaticae of Khasi and Jaintia Hills: Eastern Himalayas. Dehra Dun: Mahendra Pal Singh; 2007: P. 1-382. 